\title{
The Bohemian Redaction of The Evangelium Nicodemi in Medieval Slavic Vernaculars
}

The textual roots of the Gospel of Nicodemus reach back into late antiquity: the accounts of Jesus' trial before Pilate, of Joseph of Arimathea's imprisonment, and of Jesus' ascension - the so-called Acts of Pilate - were most likely composed in Greek, some time in the fourth century ${ }^{1}$. A version of that original apocryphon was translated into Latin by the late fifth, the date proposed for the Vienna Palimpsest containing the oldest physical fragments of the Acta Pilati in any language ${ }^{2}$. Like many other works of its genre, the Latin apocryphon enjoyed little, if any, textual stability in its long history ${ }^{3}$. Between the fifth and the ninth centuries, it was not only corrected against Greek exemplars ${ }^{4}$, but also amplified with additional narrative episodes, such as the story of the harrowing of hell (Descensus Christi ad inferos) or the discussions between Pilate and the Jewish leaders in the temple (chapter XXVIII) , and refashioned through addition of titles, epilogues, and related Pilate apocrypha. Under the title Gesta Salvatoris, it began to proliferate in the ninth century, albeit in a form substantially different from that of the Vienna Palimpsest; even after it came to be known as the Evangelium Nicodemi in the twelfth century, it continued to grow and forge new textual alliances, not only with extraneous works but among its own divergent lines of transmission as well.

\footnotetext{
${ }^{1}$ The exact date and milieu are still a matter of debate; for recent assessment of its origin, see M. SснӓRTL, "Nicht das ganze Volk will, dass er sterbe." Die Pilatusakten als historische Quelle der Spätantike, Frankfurt am Main 2011 (Apeliotes 2011 Studien zur Kulturgeschichte und Theologie, 8), p. 12-28; and R. Gounelle, Un nouvel évangile judéo-chrétien? Les Actes de Pilate, [in:] The Apocryphal Gospels within the Context of Early Christian Theology, ed. J. SCHRöTER, Leuven 2013, p. 357-402. ${ }^{2} \mathrm{M}$. Despineux, Une version latine palimpseste du V siècle de l'Évangile de Nicodème (Vienne, ÖNB MS 563), Scr 42, 1988, p. 176-183. The text was edited by G. PHILIPPART, Les fragments palimpsests de l'Évangile de Nicodème dans le Vindobonensis 563 (Ve s.?), AB 107, 1989, p. 171-188.

${ }^{3}$ On the transmission of apocryphal works, see S. Johnson, Apocrypha and the Literary Past in Late Antiquity, [in:] From Rome to Constantinopole: Studies in Honour of Averil Cameron, ed. H. Amirav, R.B. TER HaAR Romeny, Leuven 2007, p. 47-66.

${ }^{4}$ Cf. Z. Izydorczyк, On the Evangelium Nicodemi before Print: Towards a New Edition, Apocr 23, 2012, p. 97-114.

${ }^{5}$ For the Descensus, see H.C. KIM, The Gospel of Nicodemus: Gesta Salvatoris, Toronto 1973 (Toronto Medieval Latin Texts, 2), p. 35-49; cf. also Evangelia apocrypha, ed. C. von Tischendorf, ${ }^{2}$ Leipzig 1876, p. 389-409; for chapter XXVIII, see ibidem, p. 409-412.
} 


\section{The Bohemian Redaction}

Most extant Latin manuscripts of the Evangelim Nicodemi transmit what, since Dobschütz ${ }^{6}$, has been referred to as Latin tradition A, best known from Kim's edition of Einsiedeln, Stiftsbibliothek 326 (Census 75$)^{7}$. However, at least two other, significantly different textual traditions, Latin B and Latin C, were also copied throughout the Middle Ages, as was a range of non-conforming recensions ${ }^{8}$. The Bohemian Redaction belongs to that last category ${ }^{9}$ and is remarkable as much for its hybrid textuality as for its widespread and enduring vernacular legacy. It survives in ten fifteenth-century Latin manuscripts, predominantly from Upper Austria, Bohemia, Moravia, and Poland ${ }^{10}$. The manuscripts are thus relatively late and confined to one region of Europe.

Textually, the Bohemian Redaction oscillates between Latin traditions A and $B$. The early chapters tend to follow Latin A, but often adding unique details drawn from Latin B. Its dependence on Latin B increases in the account of Joseph of Arimathea's return to Jerusalem (ch. 15) and culminates in the accounts of the three rabbis who witnessed Christ's ascension and of the finding of Carinus and Leucius, the two sons of Simeon, raised from the dead (ch. 16-17). The Descensus, however, reverts to Latin A but, again, incorporating occasional passages from Latin B. This textual patchwork, celebrating what editors might call horizontal contamination, ends with Pilate's letter to Claudius and a short epilogue explaining that Nicodemus's account was discovered in Jerusalem by emperor Theodosius and through him it passed down to us. Most manuscripts of the Bohemian Redaction divide this entire composition into chapters, some with headings highlighting the key events. In four manuscripts (Census 63, 64, 116, 340), this mixed form of the Evangelium Nicodemi is followed by a legend of the Cross (Narrat quedam historia Grecorum...) and by a story of the healing of Tiberius (Cura sanitatis Tiberii) ${ }^{11}$.

\footnotetext{
${ }^{6}$ E. von Dobschütz, Nicodemus, Gospel of, [in:] A Dictionary of the Bible, ed. J. Hastings, vol. III, New York 1919, p. 544-547.

${ }^{7}$ Z. Izydorczy , Manuscripts of the "Evangelium Nicodemi": A Census, Toronto 1993. Throughout this paper, I will refer to the manuscripts of the Evangelium Nicodemi by their Census number.

${ }^{8}$ For a brief description of those versions, see IDEM, The Evangelium Nicodemi in the Latin Middle Ages, [in:] The Medieval Gospel of Nicodemus: Texts, Intertexts, and Contexts in Western Europe, ed. IDEM, Tempe 1997, p. 46-54.

${ }^{9}$ Z. Izydorczyk, W. Wydra, A Gospel of Nicodemus Preserved in Poland, Turnhout 2007 (CC.SA Instrumenta, 2), p. 18.

${ }^{10}$ The manuscripts in question are: Brno, Moravská zemská knihovna MS Mk 79 (Census 33); České Budějovice, Státní vědecká knihovna MSS 1 VB 28 (Census 63) and 1 VB 58 (Census 64); Gdańsk, Biblioteka Polskiej Akademii Nauk MS Mar. F. 202 (Census 87); Klosterneuburg, Stiftsbibliothek MS 495 (Census 116); Olomouc, Kapitulní knihovna CO 487 (not in Census); Schlägl, Stiftsbibliothek MSS 156 Cpl. 145 (Census 340) and 187 Cpl. 95 (Census 341); Wrocław, Biblioteka Uniwersytecka MSS I F 509 (Census 412) and I F 742 (Census 415).

${ }^{11}$ The legend of the Cross has been printed from a manuscript once owned by Rev. Dr. Ginsburg of Virginia Water but now lost (Census 436) by E.M. Thompson, Apocryphal Legends, JBAA 37, 1881, p. 241-243; the Cura sanitatis Tiberii, which occurs also in Olomouc CO 487, was edited by E. voN
} 
The Latin B text used by the Bohemian redactor probably came from the textual sub-branch characterized by extensive omissions (Latin B2). At one point, Latin B2 manuscripts delete a portion of the exchange between Pilate and the Jewish leaders only to resume with the phrase Post multas altercationes inter Pilatum et Iudeos... The Bohemian redaction retains that phrase (in the form Post multas igitur altercaciones quas habuit Pylatus cum Iudeis..., Census 87, fol. 95v) even though it supplies the excised text from Latin A. None of the extant manuscripts of Latin B2 corresponds closely enough to the Bohemian Redaction to be called its immediate source, but four manuscripts come fairly close to $\mathrm{it}^{12}$.

The nature of the redactor's Latin A source is more difficult to assess. However, the short epilogue that concludes the apocryphon occurs also in eight late-twelfthto fourteenth-century Latin A manuscripts of French or British provenance, four of which preserve portions of the so-called Andrius Compilation ${ }^{13}$. The Bohemian redactor's Latin A source may have thus originated in Western Europe and may have been related - through the epilogue as well as through the legend of the Cross and the Cura sanitatis Tiberii - to the cluster of texts compiled by Andrius. A textual link between Britain and/or France and central Europe would be quite natural in the latter half of the fourteenth century, when both political and religious ties between the two regions were quite strong ${ }^{14}$.

\section{Byelorussian translation}

This idiosyncratic Latin redaction was the direct source of a late medieval translation into Byelorussian. That Byelorussian rendition is currently known from two manuscripts, one in St. Petersburg, Publičnaja Biblioteka, Osnovnoe sobr. MS Q.I.391 (siglum P), and another in Moscow, Gos. Istoričeskij Muzej,

Dовsснüтz, Christusbilder. Untersuchungen zur christlichen Legende, Leipzig 1899 (Texte und Untersuchungen zur Geschichte der altchristlichen Literatur, XVIII.3), p. 209-214, 157**-203**; Dobschütz knew manuscripts Census 63 and Census 64 of the Bohemian redaction.

${ }^{12}$ They are Padova, Biblioteca Antoniana MS 473 Scaff. XXI (Census 247); Venezia, Biblioteca Nazionale Marciana MS Marc. Lat. XIV, 43 [It. II, 2] (Census 387); Vallbona, Santa Maria de Vallbona MS 3 (Census 369); and London, British Library MS Add. 29630 (Census 145). It should be noted, however, that some characteristic Latin B passages surface also in other manuscript copies of the Evangelium Nicodemi written in central or eastern Europe, such as Prague, Knihovna metropolitní kapituly MS N LIV (Census 299), which do not carry the Bohemian Redaction.

${ }^{13}$ Manuscripts that place the epilogue after the full text of the Evangelium Nicodemi include Cambridge, St. John's College MS E.24 (Census 53); London, British Library MS Cotton Vesp. E. I (Census 151); Oxford, Bodleian Library MS Bodl. 556 (Census 228); and Rouen, Bibliothèque municipal MS U65 (Census 333); manuscripts with the Andrius Compilation include Cambridge, Magdalene College MS F.4.15 (Census 49); London, British Library MS Harley 4725 (Census 156); Paris, Bibliothèque nationale MS Lat. 1722 (Census 253); Paris, Bibliothèque nationale MS Lat. 3338 (Census 259). On the Andrius Compilation, see E.C. Quinn, The Penitence of Adam: A Study of the Andrius MS, Mississipi 1980 (Romance Monographs, 36).

${ }^{14}$ Cf. A. Thomas, A Blessed Shore: England and Bohemia from Chaucer to Shakespeare, Ithaca-London 2007. 
Sinodal'noe sobr. MS 203 (367) (siglum M), both dated to the fifteenth century ${ }^{15}$. In both, the apocryphon follows a passion narrative, entitled Мүка господа нашого

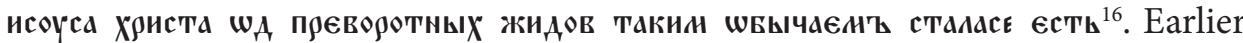
scholars tended to see the Gospel of Nicodemus as part of this passio, but the two appear to be independent of each other ${ }^{17}$. In both manuscripts, a prayer to the Blessed Virgin Mary and her son, ending with an Amen, clearly marks the end of the passion narrative:

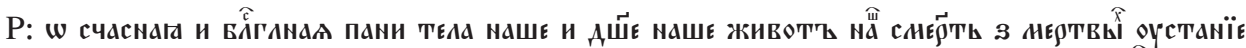

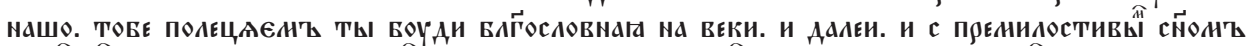

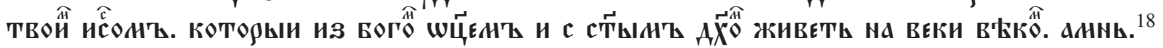

After this emphatic conclusion, the apocryphon begins with what appears to be its own title:

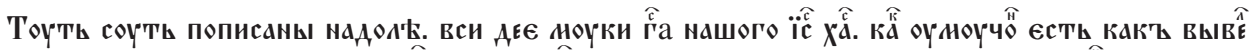
шцุ

This title echoes the titles in three manuscripts of the Latin Bohemian Redaction (Census 412, 415, and 341):

Census 412: Incipiunt gesta saluatoris domini nostri Ihesu Christi et qualiter passus sit et qualiter infernum destruxit que inuenit Theodosius imperator in Ierusalem in pretorio Pylati in codicibus publicis (fol. 371ra)

Like its Latin counterparts, the title in P not only invokes Theodosius as the discoverer of the document in Pilate's public codices but also alludes to Christ's passion and to the effects of his descent into hell.

\footnotetext{
${ }^{15}$ See A. De Santos Otero, Die handschriftliche Überlieferung der altslavischen Apokryphen, vol. II, Berlin-New York 1981, p. 75, an. 54, and p. 82, an. 91. These two manuscripts were frequently discussed in the nineteenth century; for a list of the early studies, see Е.Ф. КАРСКИЙ, Западнорусский сборник XV-го века, принадлежащий Императорской публичной библиотеке, Q.I. № 391, ИОРЯС 2(4), 1897, p. 965. F.J. Тномson, Apocrypha Slavica: II, SEER 63.1, 1985, p. 82, (w) indicates that Santos Otero's no. 86 (Moscow, Gos. Istoričeskii Muzei, Sbornik E.V. Barsov) also carries the same redaction. A. BRÜCKner, Z rękopisów petersburskich. III. Powieści," PF 5, 1899, p. 390, writes, Inny czy ten sam tekst powtarza się w rękopisie kijowskim p.t. Myкa Eзyca (przytoczonym u PETROVA, Opisanie rękopisów muzeum kijowskiego 492), którego bliżej nie znamy; this manuscript does not appear to be listed by Santos Otero.

${ }^{16}$ Both the passion and the Gospel of Nicodemus have been printed from the St. Petersburg manuscript by Н.М. Тупиков, Страсти Христовы в западно-русском списке XV века, Санкт-Петербург 1901 (Памятники древней письменности и искусства, 140), with variants from M. All my remarks are based on that edition.

${ }^{17}$ F.J. Thomson, op. cit., p. 82, claims that the Petersburg and Moscow manuscripts contain a completely different, fifteenth-century translation of a similar Latin passio Christi ... which used the Evangelium Nicodemi as one of its sources. However, the passio itself does not quote from or mention the Gospel of Nicodemus.

${ }^{18}$ Н.М. Тупиков, op. cit., p. 36.

${ }^{19}$ L. cit.
} 
The assumption that the Byelorussian Gospel of Nicodemus forms part of the preceding passio may be related to the fact that the apocryphon is broken up into several titled sections, the sections are rearranged, and at one point some extraneous material is inserted. The scribe responsible for these rearrangements was probably not the translator but a compiler who used a complete copy of the translation. He placed the accounts of the trial, crucifixion and entombment (prologue to ch. 11.3) immediately after the conclusion of the preceding passio ${ }^{20}$, perhaps to counterbalance the heavy emphasis on the Blessed Virgin Mary in the latter ${ }^{21}$. He brought the Nicodemean narrative to the entombment, that is, to the same point at which the preceding passio ended, and then switched the focus, first, to the story of Pilate and Tiberius, and then to the harrowing of hell ${ }^{22}$, both drawn from the Legenda aurea (ch. LIII and LIV, respectively) ${ }^{23}$. Jacobus de Voragine's abridged account of the harrowing must have attracted the full Descensus from the Gospel of Nicodemus (ch. 18.1-27.5) ${ }^{24}$, complete with Pilate's letter addressed to Tiberius, which the scribe placed immediately after the material from the Legenda ${ }^{25}$. At this point, perhaps somewhat belatedly, the scribe returns to the story of the discovery of Laucius and Carinus, the two narrators of the Descensus (ch. 16.1-17.3) ${ }^{26}$. The leftover portion of the apocryphon, the story of the imprisonment and deliverance of Joseph of Arimathea (ch. 12.1-15.6), is placed at the very end ${ }^{27}$ and concluded with an epilogue explaining how the whole story came to be known ${ }^{28}$.

When all these various sections are put back into their proper sequence, they add up to a practically complete Gospel of Nicodemus:

prologue and ch. 1.1-11.3

ch. $12.1-15.6$

ch. $16.1-17.3$

ch. 18.1- 27.5 (with some omissions)

\author{
Tupikov, Strasti, p. 36-50 (P, fol. 16r-22v) \\ Tupikov, Strasti, p. 75-83 (P, fol. 34r-38r) \\ Tupikov, Strasti, p. 69-74 (P, fol. 31v-34r) \\ Tupikov, Strasti, p. 61-68 (P, fol. 27r-30v)
}

\footnotetext{
${ }^{20}$ Ibidem, p. 36-50.

${ }^{21}$ Cf. Е.Ф. КАРСКИЙ, ор. cit., p. 983.

${ }^{22}$ Н.M. Тупиков, op. cit., p. 50-61.

${ }^{23}$ Legenda aurea, rec. Th. Graesse, ${ }^{2}$ Lipsiae 1850, p. 231-234, 241-244. The passage linking the Pilate / Tiberius narratives and the story of the Christ's descent also seems to depend on the Legenda aurea, ch. LIV, p. 235-237. The dependence on the Legenda aurea was noted already by E. $\Phi$. Карский, op. cit., p. 991.

${ }^{24}$ Н.M. Тупиков, op. cit., p. 61-68.

${ }^{25}$ Ibidem, p. 68-69. The Descensus abridges some of the devils' laments and omits the episodes of Christ committing the Old Testament saints to archangel Michael and of the saints' encounter with Enoch, Elijah, and the Good Thief in paradise, possibly because these episodes were already treated at length in the interpolation from the Legenda.

${ }^{26}$ H.M. Тупиков, op. cit., p. 69-74. The chapter presenting this narrative ends with a reference to the

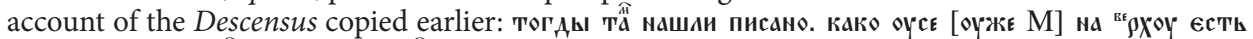

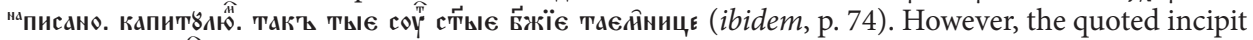

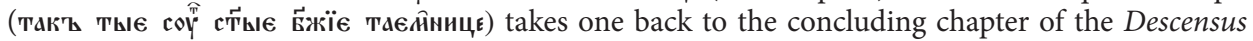
rather than to its beginning.

${ }^{27}$ Ibidem, p. $75-83$.

${ }^{28}$ Ibidem, p. 83-84.
} 
ch. 28 (Epistola Pilati)

epilogue
Tupikov, Strasti, p. 68-69 (P, fol. 30v-31r)

Tupikov, Strasti, p. 83-84 (P, fol. 38r)

Despite the drastic rearrangements, in both manuscripts $\mathrm{P}$ and $\mathrm{M}$, the Byelorussian translation is recognizably dependent on the Latin Bohemian Redaction. The scribe broke up the apocryphon into sections not at random but at the points at which at least three Latin manuscripts (Census 412, 415, and 87) of the Redaction break up the text with titles or large initials. The translator's dependence on the Bohemian Redaction is even more apparent in the presence of idiosyncratic textual modifications that are not found in any other version of the Latin apocryphon. For example, the prologue to the Byelorussian version ends, as in the Bohe-

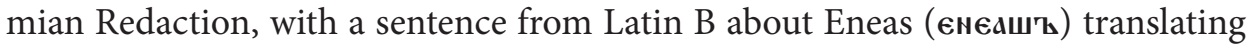
into Greek what Nicodemus had written in Hebrew

Census 412: ad cognitionem omnium fidelium credencium in Christo (fol. 371ra)

P:

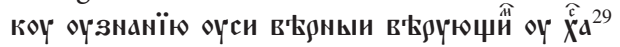

Other examples of idiosyncratic readings shared by the Latin Bohemian Redaction and the Byelorussian version are easy to find. In ch. 1.1, when the Jews bring Jesus before Pilate, he orders him unbound and sends him to Caiaphas,

Census 412: $\quad$ quia prope erat domus Pylati a domo Cayphe (fol. 371ra)

P: $\quad$ Бо Близко вь

Shortly afterwards, the Jews claim to know not only Jesus' parents, but also his brothers:

Census 412: $\quad$ et omnes fratres eius bene nouimus (fol. $371 \mathrm{rb}$ )

P:

The last two passages, unique to the Bohemian Redaction, are not found outside it. Later in the narrative, the cursor explains to Pilate that he honored Jesus because he had seen Jewish children do the same when he had been sent

Census 87: $\quad$ ad cesaream Allexandri (fol. 94v) 32

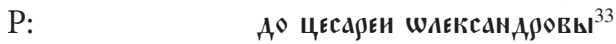

rather than "Hierosolimam ad Alexandrum," the reading in the celebrated Einsiedeln manuscript (Census 75) 34 $^{34}$ and in all other textual traditions of the Latin Evan-

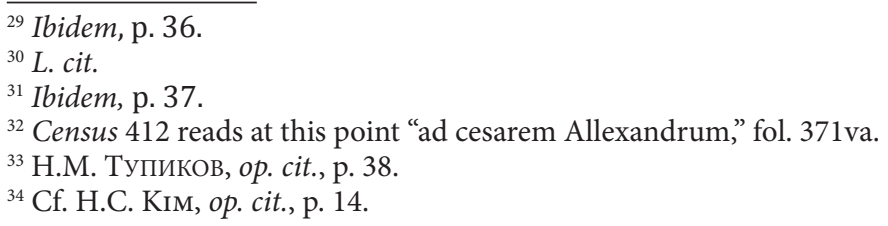


gelium Nicodemi. The Byelorussian text clearly follows the Bohemian Redaction in this unusual detail.

The accounts of the trial, crucifixion and ascension in the Byelorussian translation have exactly the same mixture of Latin A and Latin B readings as does the Bohemian Redaction; and in both, the Descensus is mostly Latin A, with only some additions from $B$. The translation ends with the same rare epilogue that usually concludes the Latin Bohemian redaction ${ }^{35}$ :

Census 87: $\quad$ Nunc ergo fratres karissimi hanc leccionem quam audistis Nichodemus hebraicis litteris commendauit ... sicque per istum imperatorem ad nostram noticiam deuenerunt (fol. 101v)

P:

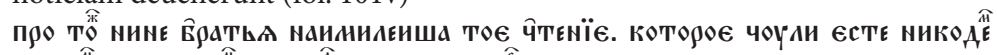

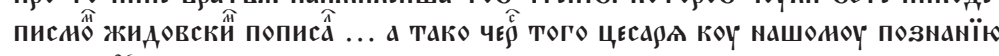
пришли

Where the Latin manuscripts of the Bohemian redaction diverge from one another, the Byelorussian translation typically follows Census 87 (the Gdańsk manuscript), with which it exhibits numerous striking correspondences. Usually, it renders Census 87 word for word, reproducing the same lexical and, whenever possible, syntactic patterns. For example, in ch. $4.5, \mathrm{P}$ distributes the verbs "crucifigere" and "occidere" exactly as Census 87 and in contrast to Census 412 :

Census 412: $\quad$ pro eo quod dixit se esse filium dei et regem iudeorum wultis eum crucifigere? Dicunt ei omnes vna uoce Etiam (fol. 373rb)

Census 87: $\quad$ propter hoc quod dixit se filium dei et regem wultis eum occidere? Dicunt ei omnes vna uoce crucifigatur (fol. 95v)

P:

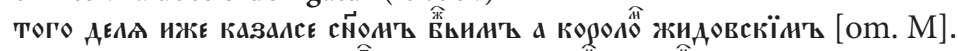

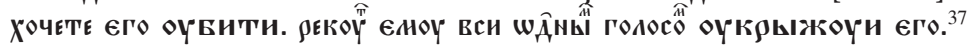
(emphasis mine)

Occasionally, Census 87 and the Byelorussian translation share the same abridgements. Thus, both omit part of the exchange between the Jews and the three rabbis from Galilee in ch. 14.2, in which the Jews ask why the rabbis spread rumors among the people ${ }^{38}$. In the Descensus, ch. 24.1, both cut out a portion of Adam's address to Christ and the reference to Eve, abridging the text in a characteristic manner (the full text is preserved in Census 412):

Census 412: $\quad$ Moxque pater Adam... dicebat Ecce manus que me plasmauit testificans omnibus dicebatque ad dominum Aduenisti redemptor mundi ad liberandum... Similiter et uxor eius Eva prouoluta pedibus domini manus

\footnotetext{
${ }^{35}$ The epilogue is missing from Census 412 and 415 because they do not complete the text.

${ }^{36}$ H.M. Тупиков, op. cit., p. 83-84.

${ }^{37}$ Ibidem, p. 44.

${ }^{38}$ The sentence does occur in other manuscripts of the Bohemian Redaction, such as Census 412:

Et si oracionem uenistis dare deo in deliramento isto quare murmurastis coram populo (fol. $376 \mathrm{vb}$ ).
} 
eius deosculans... dicens Ecce manus que me plasmauerunt testificans omni bus sanctis (fol. 382va-b)

Census 87: $\quad$ Moxque pater Adam... dicebat ecce manus que me plasmauit testificans omnibus sanctis. Et extendens dominus manus... (fol. 101r)

P:

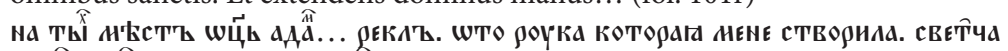

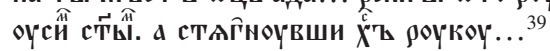

And not infrequently, the translation agrees with Census 87 even in minute verbal details, to the point of reproducing obvious misreadings or misspellings of the Latin scribe. For example, it dates the passion п今ึ кнлжєнинт мисада [i.e., миса Ad] вєльлишна ${ }^{40}$, which corresponds uniquely to "sub consulatu nisi et vellionis" of Census 87 (fol. 94r). All other extant manuscripts of the Bohemian Redaction - and, in fact, most other textual traditions - have the standard form of the first name: "ruffi," "rufferii" or "rufferni." Such examples of the Byelorussian text reproducing pecularities of Census 87 could be easily multiplied; they can be found in ch. 2.1:

Census 75: $\quad$ Pilatus uero uidens timor adprehendit eum et coepit exsurgere de sede sua ${ }^{41}$

Census 412: Videntes itaque Pylatus et omnes qui assistebant ei obstupefacti sunt et ceperunt ad inuicem mirari ac dicere (fol. 372ra-b)

Census 87: Videns namque Pylatus et omnes qui astabant ei stupefacti sunt, et ceperunt ministri ad invicem dicere (fol. $94 \mathrm{v})$

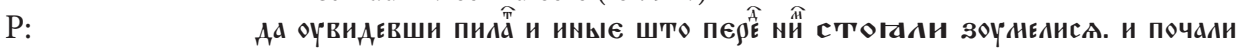
слоуги АЕжи совою Говоритин ${ }^{42}$ (emphasis mine)

in ch. 9.2:

Census 75:

et nunc dicitis quia ego regem odio ${ }^{43}$

Census 412:

Et nunc dicitis quia ego odio habeo Cesarem (fol. 374va)

Census 87:

Et nunc dicitis quia ego habeo cesarem (fol. 96r)

$\mathrm{P}$ :

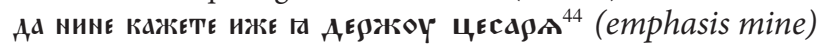

and in ch. 12.2:

Census 75: hoc facto congregati iusserunt principes Annas et Cayfas presentari Ioseph ${ }^{45}$

Census 412: et sedentes iusserunt adducere eum cum infinita multitudine (fol. $375 \mathrm{vb}$ )

Census 87: $\quad$ Et sedentes iusserunt adducere eum finita mu/leta (fol. 97r)

$\mathrm{P}$ :

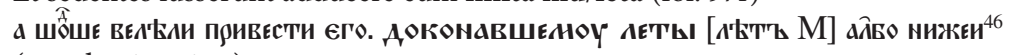
(emphasis mine)

\footnotetext{
${ }^{39}$ H.М. Тупиков, op. cit., p. 67.

${ }^{40}$ Ibidem, p. 36.

${ }^{41}$ H.C. KIm, op. cit., p. 16.

${ }^{42}$ H.M. Тупиков, op. cit., p. 40.

${ }^{43}$ H.C. KIM, op. cit., p. 24.

${ }^{44}$ H.М. Тупиков, op. cit., p. 47.

${ }^{45}$ H.C. КIм, op. cit., p. 28.

${ }^{46}$ H.M. Тупиков, op. cit., p. 76.
} 
Despite such striking agreements, occasional discrepancies between Census 87 and $\mathrm{P}$ suggest that the translator did not use the Gdańsk manuscript itself but a closely related, perhaps a sister copy. Thus, describing the Jews' arrival at Leucius and Carinus's house in ch. 17.2, the Byelorussian text, in contrast to Census 87 but in agreement with Census 412, makes no reference to the way the Jews voiced their request:

Census 412: $\quad$ prostrauerunt se ad in terra adorauerunt eos et erecti dixerunt ad eos (fol. 380ra) Census 87: $\quad$ prostrauerunt se in terra adorantes eos Et ertā [?] uoce dixerunt ad eos (fol. 99r-v)

P:

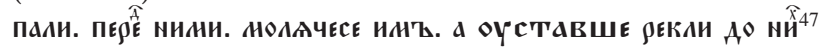
(emphasis mine)

In the report of the Jews' threats against Joseph of Arimathea (ch. 12.1), the translation includes an ill-fitting variant that might have been transferred from its Latin exemplar. Explaining that they cannot deal with Joseph right away because the holy day is dawning, the Jews add that ани писла недостой єсии ${ }^{48}$ (еmphasis mine). All extant manuscripts of the Bohemian Redaction, including Census 87, read at this point nec sepultura dingus es, but the translator's source text may have read here "scriptura," not an unlikely misreading if the word had been abbreviated in an earlier Latin copy ${ }^{49}$. Thus although the Gdańsk manuscript remains very close to the translator's source text, it is probably not identical with it.

\section{Polish translation}

It was once assumed that this Byelorussian translation of the Gospel of Nicodemus must have been carried out from a Polish source because of a large number of polonisms in the St. Petersburg copy ${ }^{50}$. The Polish source survives, it has been argued, in the codex of Lawrence of Łask, both in the Sprawa chędoga and in the two Nicodemean narratives that appear later in the codex, one immediately after the Sprawa, on fol. 127r, and the other on fol. 260r. However, a close comparison of those texts reveals that there is little merit to this argument.

Firstly, the Gospel of Nicodemus that begins on fol. 260r of Laurence's codex has no connection with the Byelorussian translation because it is not a copy of

\footnotetext{
${ }^{47}$ H.М. Тупиков, op. cit., p. 73.

${ }^{48}$ Ibidem, p. 75.

${ }^{49}$ None of the known Latin manuscripts of the Bohemian redaction reads "scriptura" or abbreviates the word "sepultura." However, such an error does occur, for instance, in the twelfth-century manuscript Munich, Bayerische Staatsbibliothek Clm 5127 (Census 183), fol. 34r, from Beuerberg, dioc. Freising.

${ }^{50}$ Е.Ф. КАРСКИЙ, ор. cit., p. 994, suggested that the Byelorussian text could have been translated directly from Latin, the suggestion born out by the comparison between Census 87 and $\mathrm{P}$ above. However, A. BRÜCKner, Apokryfy średniowieczne. Część Druga, Kraków 1905 (Rozprawy Akademii Umiejętności, Wydział Filologiczny, II.25), p. 260, 281-282, an. 1, and J. JANów, Legendarno-apokryficzne opowieści ruskie o męce Chrystusa, Warszawa 1931, p. 11-14, insisted that the source text must have been Polish.
} 
the Bohemian Redaction. Rather, it presents a completely different recension of the apocryphon, translated from a highly idiosyncratic Latin Evangelium Nicodemi preserved in two Kraków manuscripts, Biblioteka Jagiellońska MS 1509 (Census 127), and Biblioteka Polskiej Akademii Umiejętności MS 1713 (not in Census) ${ }^{51}$. As such, it definitely could not have served as a source for the Byelorussian translator.

Secondly, the Byelorussian translation has little in common with the "short" Gospel of Nicodemus beginning on fol. 127r, immediately after the Sprawa chędoga, and comprising the stories of Joseph of Arimathea and of Christ's descent into hell ${ }^{52}$. This Polish version is based entirely on tradition Latin A, with no amplifications from Latin B, which are so characteristic of the Latin Bohemian Redaction and of its Byelorussian counterpart. The Byelorussian translator could not have produced his version by drawing on this particular Polish model either.

And thirdly, the fragments of the Gospel of Nicodemus incorporated into the Sprawa chędoga itself were also taken from a text belonging to the Latin A tradition $^{53}$. Those fragments are interpolated into a passion narrative and heavily altered to fit the context, but what is discernible shows very few traces of the Bohemian Redaction ${ }^{54}$. If the reflexes of the Gospel of Nicodemus in the Sprawa were quarried from a pre-existing Polish translation, that translation lacked the bulk of the features that account for the uniqueness of the Bohemian Redaction and the Byelorussian translation.

It appears, therefore, that if a Polish translation of the Bohemian Redaction once existed, it left very few traces in Polish manuscripts. However, several seventeenth-century Russian manuscripts preserve portions of the Descensus derived apparently from the Bohemian Redaction and entitled Чюдаєв' пє९євод

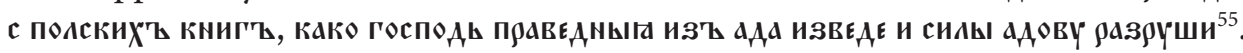
Polívka and Janów assumed that those excerpts indeed derived from the same Polish translation that stood behind the Byelorussian version ${ }^{56}$. But since the Byelorussian text, as I have shown, is closely tied to the Latin of the Gdańsk manuscript,

\footnotetext{
${ }^{51}$ The latter manuscript has been first identified by Marcello Piacentini, Un importante contributo allo studio degli apocrifi. Il Vangelo di Nicodemo in Polonia: tradizione latina e traduzione polacca, SSla 8, 2011, p. 195-201. See also Jan CzubeK, Katalog rękopisów Akademii Umiejętności w Krakowie, Kraków 1912, p. 26-27. This form of the apocryphon ends with a complete chapter 16, as in Greek versions, but without the Descensus. The Polish translation follows the Latin very closely, reproducing a number of its characteristic corruptions. It has been edited, together with the Latin text from Kraków, Biblioteka Jagiellońska MS 1509, [in:] Z. IzydorczyK, W. Wydra, op. cit.

${ }^{52}$ S. Vrtel-WierczyŃski, Sprawa chędoga o męce Pana Chrystusowej i Ewangelia Nikodema, Poznań 1933, p. 133-156.

${ }^{53} \mathrm{Ibidem}$, p. $65-81$, passim. It is not clear whether the fragments embedded in the Sprawa chędoga formed part of the same translation as the "short" Gospel of Nicodemus beginning on fol. 127r.

${ }^{54}$ The two phrases that might be its distant textual echoes - "podług obiczia" (ibidem, p. 66; "secundum consuetudinem") in the description of the standard bearers holding the standards and "bandz tako" (ibidem, p. 67; "Ita fiat") in their response to Pilate's threat of beheading - may have resulted from horizontal contamination, quite common in the apocryphon's transmission history.

${ }^{55}$ J. Polívka, Evangelium Nikodemovo v literaturách slovanských, ČČMu 65, 1890, p. 450-453.

${ }^{56}$ L. cit.; J. JANów, op. cit., p. 13-14.
} 
it is unlikely to have been produced via a Polish intermediary. Moreover, the excerpts quoted by Polívka preserve details and phrasing that differ from those in the known copies of the Bohemian Redaction but are attested elsewhere in the Latin

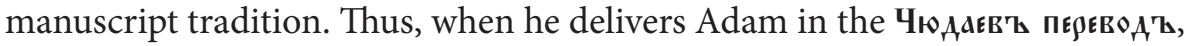

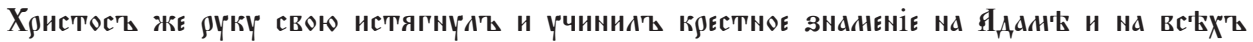

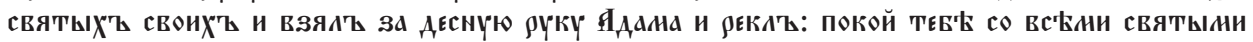
НОИАИ И ПОАВЕАНЫАН... ${ }^{57}$

This echoes the standard Latin A version, such as in the Einsiedeln manuscript (Census 75), even if the latter does not make a reference to the sign of the cross at this point:

Census 75: $\quad$ Tenens autem Dominus manum dexteram Adae dixit ad eum: "Pax tibi cum omnibus filiis tuis, iustis meis." ${ }^{58}$

The Byelorussian text reads differently, translating exactly the Latin of Census 87:

Census 87: $\quad$ Tunc saluator mundi benigne salutans Adam dixit eis pater Adam cum omnibus filiis tuis et electis meis veni. Moxque pater Adam provolutis pedibus domini manus deosculans et fortiter lacrimas fundens dicebat ... (fol. 101r)

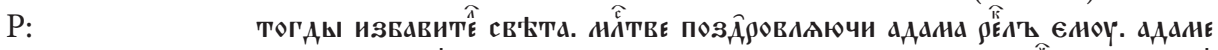

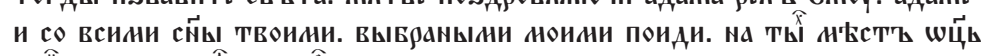

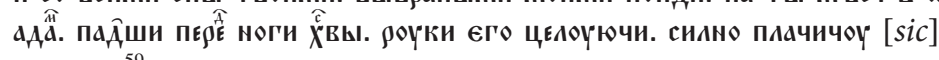


It appears, therefore, that behind the Polish translation excerpted and translated in the seventeenth-century Russian manuscripts stood a different Latin text than the one in Census 87, which stands behind the Byelorussian translation. The whole matter is worthy of a more detailed and thorough study. What is clear at this time is that the apocryphon was popular in Poland and repeatedly translated, but apparently not in the exact textual form that is preserved in the Gdańsk Latin and in St. Petersburg Byelorussian manuscripts ${ }^{60}$.

\section{Czech translation}

If absent from extant Polish manuscripts, the Bohemian Redaction does survive in at least three fifteenth-century Czech ones ${ }^{61}$. The Czech translation includes

\footnotetext{
${ }^{57}$ J. Polívka, op. cit., p. 452.

${ }^{58}$ H.C. Kiм, op. cit., p. 44.

${ }^{59}$ H.M. Тупиков, op. cit., p. 67.

60 The Nicodemean material from the Sprawa occurs also in other Polish passions, such as the Rozmyślania przemyskie. Moreover, the Rozmyślania may preserve fragments of yet another Polish translation of the Evangelium Nicodemi derived from tradition Latin A; see Z. IZYDORCZYK, W. Wydra, op. cit., p. 33, an. 1.

${ }^{61}$ They are Praha, Královská kanonie premonstrátů na Strahově MS DR III 32 (dated 1442; siglum S); Brno, Moravská zemská knihovna v Brně MS MK97 (dated 1453); and Praha, Národní knihovna
} 
most of the details unique to the Latin recension as well as its characteristic mixture of Latin A and Latin B. However, on several occasions the Czech translator amplifies the text by inserting alternative accounts of the same episode. For example, the discovery of Leucius and Carinus is presented, first, as in all manuscripts of the Bohemian Redaction, on the basis of Latin B, but it is then immediately followed by the Latin A version of the same event. The translator made no attempt to reconcile the two accounts, content to place one after another and, consequently, to repeat some of the same material ${ }^{62}$. Similarly, the Czech translation presents two accounts of Adam's and Eve's prayers to Christ; and the Descensus is concluded in the same manner ${ }^{63}$.

In addition to providing alternative accounts of the same episodes, the Czech translation preserves certain passages present in Latin A but absent from all known Latin manuscripts of the Bohemian Redaction, such as, for example, the devils' questions and laments related to the pseudo-Augustinian Sermo $160^{64}$. It remains to be determined who was responsible for these amplifications, the scribe who compiled the Latin text which served as the Czech translator's source; the translator himself, who used two or more Latin manuscripts; or perhaps a later Czech redactor, who amplified an already existing Czech version of the Bohemian Redaction with material from another Latin or Czech source ${ }^{65}$. Whoever it was, his aim must have been to create a fuller, more comprehensive version of the apocryphon than the one offered by any of his sources, even at the cost of repetitiveness.

The Latin text underlying this Czech translation differed from both the Latin Gdańsk (Census 87) and the Byelorussian St. Petersburg (P) versions in numerous details. Czech readings often correspond to those in the majority of Latin witnesses of the Bohemian Redaction, and various peculiarities of the Gdańsk and St. Petersburg copies are absent. For example, the Czech version includes certain passages omitted in Census 87 and P, as in ch. 14.2:

MS XX A 4 (dated 1472). This Czech version was originally published on the basis of S by V. HANKA, Čtenie Nikodemovo: co sě dálo při umučeni pane. Pověst krásná o dřevu křiže svatého. Knižky, kterak Tiberius poslal po Ježíše Voluziána, Praha 1860, but with unacknowledged corrections and additions from another Czech version. More recently, the Strahov manuscript has been edited for Próza Českého Středověku (Praha 1983), and all my references are to this later edition. The other Czech version (Národní knihovna MS XVII B 15), used by Hanka, is based on a straightforward Latin A text; as far as I know, it has not been edited in full. Manuscripts of both versions have been compared and extensively discussed by J. PolívKA, op. cit., p. 263-275, 535-566. Two additional manuscripts, Praha, Národní Museum II E 7 and IV H 25, also preserve Czech texts of the Gospel of Nicodemus, but they were unknown to Polívka; it is not clear whether they carry the Czech version of the Bohemian Redaction, a text based on a Latin A source, or reflexes of yet another translation.

${ }^{62}$ Próza..., p. 260-262.

${ }^{63}$ Ibidem, p. 271-272, 275-276.

${ }^{64}$ Ibidem, p. 269.

${ }^{65}$ J. PolívkA's comparison of this translation with the one based entirely on Latin A (Prague, Narodní knihovna MS. XVII.B.15), suggests some points of contact between the two; see, for example, op. cit., p. 556. 
Census 412: $\quad$ Et si oracionem uenistis dare deo in deliramento isto quare murmurastis coram populo. (fol. 376vb)

S: $\quad$ Vy ste přišli chválu vzdávat bohu z toho oblúzenie, ježto ste mluvili přede vším lidem. ${ }^{66}$

Census 87: $\quad$ nil

P: $\quad$ nil

Elsewhere, the Czech translation follows other manuscripts of the Bohemian Redaction, such as Census 33, in omitting passages present in Census 87 and P, as in ch. 14.2:

Census 33: $\quad$ nil

S: $\quad$ nil

Census 87: $\quad$ Unde si taceremus peccatum haberemus (fol. 97v)

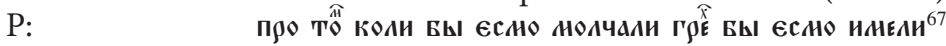

It does not share the lexical or stylistic details characteristic of Census 87 and $\mathrm{P}$, as in ch. 4.5:

Census 412: Quid fecit ut moriatur pro eo quod dixit se esse filium dei et regem Iudeorum wultis eum crucifigere? dicunt ei omnes vna uoce Etiam (fol. 373rb)

S: $\quad$ „Co jest učinil, aby umřel? Proto-li, že jest byl řekl, by byl synem božím a králem, chcete jeho ukřrižovati?” Vecechu všickni jedním hlasem vóbec: „I ovšem!”68

Census 87: $\quad$ Quid fecit ut moriatur propter hoc quod dixit se filium dei et regem wultis eum occidere Dicunt ei omnes vna uoce crucifigatur (fol. 95v)

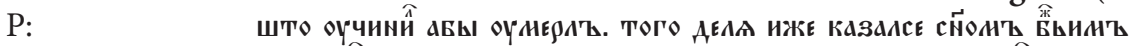

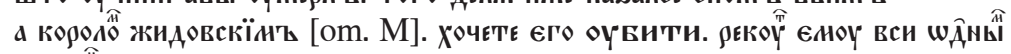
голосе оукјыжоуи єго. ${ }^{69}$ (emphasis mine)

And finally, it does not reproduce the errors and unusual readings shared by Census 87 and $\mathrm{P}$, as in ch. 1.1:

Census 75: $\quad$ non solum hoc sed et sabbatum uiolat ${ }^{70}$

Census 412: $\quad$ non solum hoc sed et Sabbatum uiolat (fol. 371rb)

S: A netoliko to, ale i svátek, točís sobotu, přerušuje $\mathrm{e}^{71}$

Census 87: $\quad$ non solum hominem sed et sabbatum violat (fol. 94r)

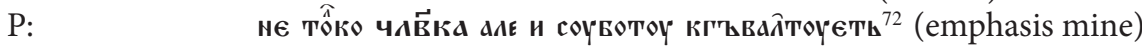

\footnotetext{
${ }^{66}$ Próza..., p. 252.

${ }^{67}$ Н.М. Тупиков, op. cit., p. 78-79.

${ }^{68}$ Próza..., p. 243.

${ }^{69}$ Н.M. Тупиков, op. cit., p. 44.

${ }^{70}$ H.C. KIM, op. cit., p. 13.

${ }^{71}$ Próza..., p. 236.

${ }^{72}$ H.M. Тупиков, op. cit., p. 37.
} 
or in ch. 23
Census 75:
O princeps Satan, possessor clauuium inferorum ${ }^{73}$
Census 412:
O princeps Sathan possessor clauium infernorum (fol. 382rb)
S:
Ó knieže Šatane, nešlechetný vládaři klíčóv a zámkóv pekelných ${ }^{74}$
Census 87:
O princeps Sathan clauium infernorum (fol. 100v)
P:

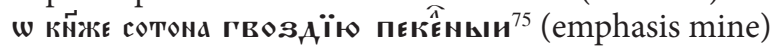

On balance, it is clear that, although both the Czech and the Byelorussian translations were derived from the same Latin redaction of the Evangelium Nicodemi, they must have been carried out independently of one another, of different, textually discrete Latin manuscripts.

The Czech version of the Bohemian Redaction is related, either through its Latin source or, perhaps, through one of its early printings ${ }^{76}$, to the $1676 \mathrm{German}^{-}$ edition entitled Evangelischer Bericht/ Das ist: Die Historia vom Leiden/ Sterben/ Aufferstehung und Himmelfahrt Jesu Christi ... Auch sind viel schoene Stueck und Geschicht dabey zu finden/ welche die Evangelisten nicht beschrieben haben, issued anonymously "von einem Liebhaber Jesu," without any indication of the place of publication $^{77}$. The Czech and German texts share some striking features not attested in any of the extant Latin manuscripts. They divide the text into titled chapters in exactly the same manner and double the introduction to the Descensus. They also agree in some minor details, such as omitting the name of Yayrus from the list of the Jews who came to accuse Jesus before Pilate and having Pilate refer to his wife as "milovnice božie" and "Liebhaberin Gottes" against the "procuratrix dei" preserved in the Latin codices. However, the German version differs from the Czech in omitting the episode of the patriarchs meeting with Enoch, Elijah, and the Good Thief in paradise and replacing it with additional prophecies and praises of Jesus. Thus, the two versions may have been translated from related manuscripts containing an early reflex, now lost, of the Latin Bohemian Redaction; or the German text may have been translated from, or at least revised on the basis of, one of the early Czech printings.

\footnotetext{
$\overline{{ }^{73} \text { H.C. KIM, op. cit., p. } 43 .}$

${ }^{74}$ Próza..., p. 270.

${ }^{75}$ H.M. Тупиков, op. cit., p. 66.

${ }^{76}$ This Czech translation found its way into print in the early sixteenth century; its earliest edition seems to have appeared in 1527; it was corrected and reissued ca. 1561, then again ca. 1563, and frequently thereafter. See the online Knihopis Digital at www.knihopis.org.

${ }^{77}$ See the digital reproduction at Universitäts und Landesbibliothek Sachsen-Anhalt, http://digitale. bibliothek.uni-halle.de/id/29177. A book with a similar title, Euangelium Nicodemi Das ist: Die Historia vom Leiden Sterben vnd Aufferstehung Jhesu Christi, printed in Marburg by Zacharias Kolbe in 1568, caries a different text; see the digital reproduction at http://ora-web.swkk.de/digimo_online/ digimo.entry?source=digimo.Digitalisat_anzeigen\&a_id=21254.
} 
The 1676 German imprint left a lasting legacy ${ }^{78}$, and, given its Czech connections, it is rather fitting that one of its descendants should bring the Bohemian Redaction back into Slavic lands. In the middle of the nineteenth century, Jan Bądzio, a Polish bibliophile farmer in the Mazury Lake District, rendered it from German into Polish and published it at his own expense in 1852 so that common folk could read it for the glory of $\mathrm{God}^{79}$. His little booklet sold out quickly, so two years later, another farmer from the same region, Wilhelm Michalczyk, corrected, expanded, and reprinted $\mathrm{it}^{80}$. There was so much interest and so much demand among the local population for his edition that in the space of fifty years it was printed eleven times $^{81}$.

This brief excursus into the Slavic versions of the Bohemian Redaction suggests that the medieval tradition of the Gospel of Nicodemus in Slavic languages as a whole is in need of a reassessment. The key Slavic manuscripts have already been identified by Santos Otero, Thomson, and others. Now the challenge is to confront the Slavic versions against Greek and Latin texts, and not as they have been constituted by Tischendorf, but as they actually survive in Greek and Latin manuscripts. Only then will the scope and character of the immensely rich Slavic tradition of the Gospel of Nicodemus tradition truly emerge from the shadows of time.

\begin{abstract}
The Bohemian Redaction of the Evangelium Nicodemi is a hybrid form of the apocryphon, combining elements of Latin traditions A and B. It circulated in central and eastern Europe, and was used as a source for late medieval translations into Byelorussian, Czech, and possibly Polish. The Byelorussian translation closely follows the idiosyncratic Latin text preserved in Gdańsk, Biblioteka Polskiej Akademii Nauk MS Mar. F. 202. The Bohemian Redaction may have also been translated into Polish, but it has left only faint traces in Polish texts. The Czech translation was carried out independently of both Byelorussian and Polish versions; it expands the text on the basis of Latin A and duplicates certain episodes. The Bohemian Redaction continued to be printed in Slavic vernaculars until the end of the nineteenth century.
\end{abstract}

\footnotetext{
${ }_{78}$ It was reissued in $1693,1700,1720,1740,1748,1752$, and many times afterwards; see www.worldcat.org under the words from the title. For its career in North America, see Z. IZYDORCZYK, C. FILLMore-Handlon, The Modern Life of an Ancient Text: The Gospel of Nicodemus in Manitoba, Apocr 21, 2010, p. 113-120.

${ }^{79}$ Czytania nabożne ku chwale Boga. Książka dla ludu, ed. Jan BĄDzIo, Jansbork 1852. On Bądzio, see R. Otello, Działacze religijni ewangelickich Mazur w walce o język polski (1848-1945), http://www. luteranie.pl/diec.mazurska/pl/biuletyn/DzialaczeMazur.htm.

${ }^{80}$ Ewangelia Nikodema, albo krótka wiadomość o żywocie Odkupiciela naszego Pana Jezusa Chrystusa, którq napisał Nikodem książę Żydowskie, jak on sam był widział i doświadczył, gdyż był nietylko Rabinem i nauczycielem Żydowskim, ale oraz tajemnym uczniem Jezusowym. Tudzież wiele innych ważnych Powieści, zdarzeń i nabożnych pieśni, ed. W. Michalczyк, Jansbork 1854.

${ }^{81}$ For a list of those editions, cf. W. CHOJNACKI, Bibliografia polskich druków ewangelickich ziem zachodnich i pótnocnych 1530-1939, Warszawa 1966, nos. 558-67, 1806.
} 
Keywords: Evangelium Nicodemi, Gospel of Nicodemus, apocrypha, Bohemian redaction of Evangelium Nicodemi, Byelorussian redaction of Evangelium Nicodemi, Polish Redaction of Evangelium Nicodemi, Sprawa chędoga

Zbigniew Izydorczyk University of Winnipeg 515 Portage Ave. Winnipeg, MB R3P 2M7

Canada z.izydorczyk@uwinnipeg.ca 